\title{
Research on the content of pathogenic micromycetes and benz(a)pyrene in soils of urbanized territories of Perm Krai
}

\author{
Emma Voronina ${ }^{12 *}$, Alevtina Balandina ${ }^{2}$, Tatiana Mazunina ${ }^{1}$, and Svetlana Dubrovina ${ }^{2}$ \\ ${ }^{1}$ Perm Institute (branch) of FSBEI of HE "Russian University of Economics named after \\ G.V.Plekhanov", 614070, Gagarin Boulevard, 57, Perm, Russia \\ ${ }^{2}$ FSBEI of HE "Perm State Pharmaceutical Academy of the Ministry of Health of Russia", 614990, \\ Polevaya str., 2, Perm, Russia
}

\begin{abstract}
The content of phytopathogenic fungi and the concentration of benz(a)pyrene in soil samples located near the oil refinery has been investigated. It has been found that in the vast majority of soil samples pathogenic micromicetes are represented by genera Fusarium, Rhizoctonia, Phytophthora, which have a negative effect on crops growth. The highest content of pathogenic micromycetes, amounting to $10 \mathrm{CFU}$ per $1 \mathrm{~g}$ of soil, was found in soil samples located directly on oil spill territory. It has been found that in an overwhelming number of soil samples, the concentration of benz (a) pyrene, which belongs to organic substances of grade I hazard, exceeds the MPC. The results of the study are consistent with earlier evidence that concentrations of pathogenic micromycetes and benz (a) pyrene are higher in anthropogenic-afected soils. This is due to the negative effect of oil hydrocarbons and benz (a) pyrene on useful soil microflora, and further settlement of the released ecological niche by pathogens. The company is given recommendations on the use of soil for cultivating technical crops or its exclusion from agricultural use.
\end{abstract}

\section{Introduction}

The aim of the work is to study the content of pathogenic micromycetes and the concentration of benz(a)pyrene in agro-sod and carbonate soil exposed to oil contamination.

The relevance of the study is due to the increased anthropogenic influence on soil, the consequence of which is its degradation, accompanied by the death of normal microflora and accumulation of toxic substances therein, many of which have carcinogenic effects.

Phytopathogenic fungi are quite common in the structure of biogeocenoses altered by human economic activity. This group of microorganisms has a large set of resistance factors to changing habitat conditions, contributing to their migration and significant variations of seasonal patterns in ecosystems.

* Corresponding author: voroninaemma403@mail.ru 
Parasitic fungi depress the growth and development of crops in different stages of growing, reducing their yields. Intensive reproduction of pathogenic micromycetes in food raw materials and foods is often accompanied by accumulation of mycotoxins, which are highly toxic secondary metabolites. Accumulating in grain or fruits, mycotoxins contaminate feed, animal body and food products of plant and animal origin.

The risk of high concentrations accumulation of benz (a) pyrene in agricultural soils is due to the high stability of this xenobiotics, the possibility of migration into raw materials for food production, as well as the ability to have a carcinogenic effect on the human body.

\section{Materials and methods}

The work was contracted by the agricultural enterprise located in Perm district of Perm Krai. The objects of the study are 13 soil samples, which are selected on the territory adjacent to the oil refinery of LUKOIL-Permnefteorgsintez LLC.

Spot samples were sampled on a test site from one or more layers by an envelope method, so that each sample is a portion of soil typical of genetic horizons or layers of a given soil type. Spot samples were taken by a spatula out of heel-ins. The combined sample was obtained by mixing at least 5 spot samples that were sampled on a single trial site. The mass of the combined sample was at least $1 \mathrm{~kg}$ [1.2].

Quantitative content of pathogenic soil micromycetes was determined in a standard way using the method of sowing from thousandth breeding in 5 times repetition. Samples were preliminary homogenized with the use of ultrasonic disperser UZDN-1 $(22 \mathrm{kHz} ; 0.44 \mathrm{~A} ; 2$ min). To suppress the development of fungi, nystatin in the amount of $50 \mathrm{mg}$ per $0.5 \mathrm{~L}$ medium was added to the nutrient environment. The calculation of microorganisms was determined by direct microscopic method using hemocytometer. Acridine orange (AO) was used as dye [3].

The number and taxonomic composition of the microorganisms complex was determined using the method of sowing on the agarized glucose-peptone-yeast medium and the Czapek's medium with the addition of hexadecane. The duration of crops incubation at room temperature was from 3 to 7 days, after which the grown colonies were counted and microscoped. The identification of fungi is carried out according to the determinants and mycological atlases [4-6] by studying their micromorphological features and cultural properties.

The concentration of benz (a) pyrene is determined by high-efficiency liquid chromatography using Agilent 1100 device with fluorimetric detector.

\section{Results and Discussion}

It has been found that in most soil samples pathogenic micromicetes are represented by the genera Fusarium, Rhizoctonia, Phytophthora (table 1).

Table 1. Pathogenic micromycetes content and concentration of benz (a) pyrene in soil samples

\begin{tabular}{|c|c|c|c|c|}
\hline \multirow{2}{*}{$\begin{array}{c}\text { Soil Sample } \\
\text { Number }\end{array}$} & \multicolumn{2}{|c|}{ The content of micromycetes CFU*/g of soil } & $\begin{array}{c}\text { Concentration of } \\
\text { benz (a) pyrene, } \\
\text { mg/kg*** }\end{array}$ \\
\cline { 2 - 4 } & $\begin{array}{c}\text { Genus } \\
\text { Rhizoctonia }\end{array}$ & $\begin{array}{c}\text { Genus } \\
\text { Phytophthora }\end{array}$ & $\begin{array}{c}\text { Genus } \\
\text { Fusarium }\end{array}$ & \\
\hline 1 & $10^{4}$ & $10^{8}$ & $10^{8}$ & 0.068 \\
\hline 2 & $10^{8}$ & - & $10^{8}$ & 0.048 \\
\hline 3 & $-^{* *}$ & $10^{8}$ & $10^{10}$ & 0.054 \\
\hline 4 & $10^{6}$ & $10^{8}$ & $10^{6}$ & 0.024 \\
\hline
\end{tabular}




\begin{tabular}{|c|c|c|c|c|}
\hline 5 & $10^{4}$ & $10^{6}$ & $10^{8}$ & 0.024 \\
\hline 6 & - & $10^{8}$ & $10^{8}$ & 0.054 \\
\hline 7 & $10^{8}$ & $10^{8}$ & $10^{10}$ & 0.013 \\
\hline 8 & - & $10^{6}$ & $10^{8}$ & 0.038 \\
\hline 9 & - & $10^{4}$ & $10^{6}$ & 0.048 \\
\hline 10 & $10^{10}$ & $10^{8}$ & $10^{10}$ & 0.059 \\
\hline 11 & $10^{10}$ & - & $10^{10}$ & 0.023 \\
\hline 12 & $10^{8}$ & - & $10^{8}$ & 0.918 \\
\hline 13 & $10^{8}$ & - & $10^{10}$ & 0.825 \\
\hline
\end{tabular}

Note: * colony forming unit; ** not found; ***benz (a) pyrene MPC in soil not more than $0.02 \mathrm{mg} / \mathrm{kg}$ [7]

In all samples there was a fairly high content of 104 to $1010 \mathrm{CFU}$ per $1 \mathrm{~g}$ of soil found. Phytophthora fungi are a pathogen of phytophthorosis, one of the most common plant diseases. Experts note the high severity of this kind of microorganisms. Fungi spread using zoospores, affect different plant species, have high plasticity and adapt well to new climatic conditions. At the same time, epiphytotic development of the disease is observed in $1-1.5$ years. There are three main forms of disease manifestation: in the form of internal necrosis of the wood crops bark or "sudden death"; die-off of shoots (branches); "branches leaves scald", which results from infestation of foliage [8].

Phytophthorosis is spread through contaminated soil, infected planting material, disease development is accelerated by weed plants growing on the site and thickened plantings. In the works [9-12] it is shown that Phytophthora affects trees of broadleaved and coniferous species, vegetable crops such as potatoes, beets, tomatoes, peppers, eggplant. It also causes phytophthorosis of fruit and berry crops, namely berries and fruits of garden strawberries, apple trees, pears, cherries, as well as some houseplants.

In all studied soil samples, we established high microbial seedness with mouldy fungi of the genus Fusarium in concentration from 106 to $1010 \mathrm{CFU} / \mathrm{g}$. Fusarium is a pathogen of fusariosis, one of the most dangerous and very common diseases of plants at any age. The disease leads to the loss of a large part of the crop and the deterioration of its quality.

Earlier in the works $[13,14]$ it was shown that all the main species of fungi of the genus Fusarium cause fusariosis and are also able to synthesize mycotoxins, among which the most common in cereal crops are deoxinivalenol (DON), T-2 and NT-2 toxins. These xenobiotics of biological origin have high chemical and thermal stability. Their accumulation was found in plants growing in almost all climatic zones, including lichens of the Arctic zone of Russia [15]. Poisoning with highly toxic mycotoxins leads to serious human diseases $[16,17]$. Caused by these poisons, plague of productive animals significantly affects solving the food problem.

The genus Rhizoctonia is the most common representative of soil-dwelling fungi. It is a disease pathogen of about 230 species of plants, including such important crops as potatoes, cotton, sugar beet. In the work [18] it is shown that the Rhizoctonia solani fungus is most common on the planting material of ornamental crops, which can cause both root and the overground part rotting, especially in herbaceous plants. The studies showed high severity of Rhizoctonia solani Kuhn, the main pathogen of the blackleg of seedling crops cabbage, cucumbers, tomatoes [19]. The accumulation of phytopathogens in the soil is facilitated by the violation of agrotechnical techniques, annual use of the same soils in farms.

Among soil samples adjacent to the oil refinery, the maximum quantity (108 to 101010 CFU/g) of phytopathogens of the genus Fusarium, Phytophthora, Rhizoctonia are present in specimens number 7 and number 10. This result emphasizes the infectious danger of these sites in the cultivation of crops, especially in the phase of plant tillering. In this 
situation it is rational to grow technical crops or temporarily abandon agricultural use of contaminated territory.

In soil samples No.11, 12 and 13, which are located directly on the territory of the oil spill, there was a high content of two genera of micromycetes - Fusarium and Rhizoctonia (1010 CFU/g).

It was established that almost all studied soil samples, except for sample No. 7, the concentration of benz (a) pyrene exceeds the MPC (table.1). At the same time, the highest concentrations of this xenobiotics are found in soil samples No.12 and 13, exceeding the MPC by 45 and 42 times respectively.

The results are consistent with earlier evidence that there is a higher concentration of pathogenic micromycetes in soils exposed to anthropogenic effects [20]. This is due to the negative impact of petroleum hydrocarbons on the growth of agronomically useful microflora and subsequent settlement of the released ecological niche by pathogens. It is advisable to abandon the cultivation of plants on these sites.

\section{Conclusions}

Our studies confirmed the need to carry out widespread control of the accumulation of phytopathogenic micromycetes and benz (a) pyrene in agricultural soils, as well as sanitary -hygienic monitoring of the safety of feed, animal and plant products for the content of mycotoxins. The permissible concentrations of mycotoxins in various products are defined in the Federal Laws - Technical Regulations of the Customs Union for specific products.

Knowledge of the ranges of phytopathogenic micromycetes allows for more effective application of pest control methods and tools, prediction and prevention of mycotoxins accumulation in grains and products of its processing, thereby reducing the risk of human and animal diseases.

According to the results of the research, the company was given recommendations on the use of soil for cultivation of technical crops or exclusion from agricultural use.

\section{References}

1. GOST 17.4.4.02-2017 Nature Protection (System of standards in nature protection). Soils. Methods of sampling and preparation of samples for chemical, bacteriological, helminthological analysis, 10, (M.: Standardinform, 2018)

2. MU 1446-76 Methodical instructions on sanitary-microbiological study of soil (with changes) Appr. Min. of Health of USSR 4.08.76.

3. D.G. Zvyagintsev, Methods of soil microbiology and biochemistry, 304 (Moscow, Publishing House of Moscow State University, 1991)

4. V.I. Bilai, Z.A. Kurbatskaya, Determiner of toxin-forming micromycetes, 236 (Kyiv: Nauk, Dumka, 1990)

5. D. Sutton, Determiner of pathogenic and conditionally pathogenic fungi, 486 (M.: Mir, 2001)

6. J. Hoult, N. Creagh, P. Snit, Bergey's Manual of Determinative Bacteriology. In 2 volumes, 800 (Moscow: Mir, 1997)

7. GN 2.1.7.2041-06 Maximum permissible concentrations (MPC) of chemicals in soil: Hygienic standards, 15, (M.: Federal Center for Hygiene and Epidemiology of Rospotrebnadzor, 2006) 
8. J. Hoult, N. Creagh, P. Snit, Bergey's Manual of Determinative Bacteriology. In 2 volumes, 800 (Moscow: Mir, 1997)

9. GN 2.1.7.2041-06 Maximum permissible concentrations (MPC) of chemicals in soil: Hygienic standards, 15, (M.: Federal Center for Hygiene and Epidemiology of Rospotrebnadzor, 2006)

10. Phytophthorosis. Official website of TU Rosselkhoznadzor for the Republic of Karelia, Arkhangelsk oblast and Nenets Autonomous Okrug. URL: https://ursn10.ru/info/nashi-konsul-tacii/fitoftoroz/ (date 12.03.2020)

11. A.N. Lazarev, Protection and quarantine of plants, 10, 50-51 (2014)

12. I.N. Aleksandrov, Protection and quarantine of plants, 2, 32-35 (2014)

13. T.A. Surina, S.N. Elansky, E.S. Mazurin, Protection and quarantine of plants, 1, 42-43 (2015)

14. G.A. Selivanova, The role of fungi of the Fusarium genus in the pathogenesis of the root system of sugar beet, Modern mycology in Russia, Materials of the 2nd Congress of Mycologists of Russia, 2, 203 (M.: National Academy of Mycology, 2008)

15. E.A. Piryazeva, G. P. Kononenko, A.A. Burkin, Agricultural Biology, 6, 179-187 (2016)

16. O.P. Gavrilova, F.B. Gannibal, T.Yu. Gagkaeva, Agricultural Biology, 51 (1), 111-118 (2016)

17. E.A. Yildirim, L.A. Ilina, K.A. Laishev, V.A. Filippova, A.V. Dubrovin, T.P. Dunyashev, G.Yu. Laptev, I.N. Nikonov, A.A. Yuzhakov, T.M. Romanenko, Yu.P. Vylko, Agricultural Biology, 53 (4), 779-786 (2018)

18. K.H. Papunidi, M.Y. Tremasov, V.I. Fisinin, A.I. Nikitin, E.I. Semyonov, Mycotoxins (in the food chain), 188, (Kazan, 2017)

19. N.R. Efimochkina, I.B. Sedova, I.A. Sheveleva, V.A. Tutelyan, of Tomsk State University, Biology, 45, 6-33 (2019)

20. S.N. Golovin, Subtropical and ornamental horticulture, 49, 289-294 (2013)

21. M.N. Ilyina, Chemical method of soil decontamination against club root disease and blackleg of cabbage in greenhouse farms: abstract of dis... candidate of agricultural sciences, 26 (Borovsk, 1966)

22. A.A. Balandina, Microbial remediation of oil-polluted agro-sod carbonate soils and technogenic surface formations in the sub-zone of southern taiga: abstract of dis... candidate of biological sciences, 29 (Perm, 2013) 